\title{
AFRIKAANSE KINDERLEKTUUR AS LITERATUUR IN 'N VEELRASSIGE SAMELEWING
}

Afrikaanse kinder- en jeugliteratuur is 'n genre wat tradisioneel sedert sy ontstaan deur blanke outeurs vir ' $n$ blanke leserspubliek geskep is. Die snelle toename in geletterdheid van die gekleurde en ook swart lae van die Suid-Afrikaanse samelewing noop hedendaagse skrywers egter om literatuur vir 'n gemengde teikengroep te konsipieer. Dit het dus nodig geword om ernstig te besin of en hoe Afrikaanse kinder-en jeugliteratuur die gekleurde kind en ook die swart kind wat Afrikaans as 'n tweede of derde taal lees, aanspreek. Daar moet gevra word of die beeld van die swarte in die Afrikaanse kinder- en jeugliteratuur die swart/bruin kind se selfbeeld opbou. Maak dit hom trots om homself te wees, of dehumaniseer dit hom deurdat hy verneder word?

'n Studie van 1500 Afrikaanse verhalende kinder- en jeugboeke wat van 1897 tot 1982 gepubliseer is, het betekenisvolle gegewens aan die lig gebring. Die teoretiese vertrekpunt wat die studie ten grondslag lê is dat alhoewel daar aanvaar word dat daar 'n gaping tussen literatuur en die eksterne werklikheid bestaan sodat eersgenoemde nie eenvoudig as 'n spieëlbeeld van laasgenoemde beskou kan word nie, en dat literêre waarde onafhanklik is van die boodskap of die "waarheidsgetroue" uitbeelding van situasies, kinder- en jeugliteratuur as sosialiseringsmedium ook ondersoek moet word. Daar word dus in hierdie studie nie ingegaan op die literêre meriete van die verhale nie alhoewel dit duidelik gestel word dat literêr-esteties minderwaardige verhale, veral die propagandatipe verhaal, hoe "positief" die boodskap ook al mag wees, selde die toets van die tyd deurstaan.

Die studie is gebaseer op 'n model wat in die kommunikasieteorie gegrond is, $\mathrm{nl}$ : WHO says WHAT to WHOM? (cf. Laswell in Smith et al, 1946:121) met klem veral op die eerste twee elemente, aangesien die kwessie van resepsie (to WHOM), 'n afsonderlike studie sou benodig. Die WHO sal veral die historiese tydperk waarin ' $n$ werk verskyn in ag neem insluitende die sosio-politieke klimaat van die era, terwyl die WHAT die waardes wat aan kinders gekommunikeer word deur die literatuur, sal ondersoek. Weens beperkte ruimte sal in hierdie artikel die WHO egter grootliks agterweë gelaat word en sal daar op die WHAT gekonsentreer word. 
Die fokus van die studie is op rasse-elemente, wat beide negatiewe rasse-elemente of te wel rassisme insluit asook posiliewe rasseelemente, waardeur ' $n$ simpatieke uitbeelding van die swarte' aangebied word. Beide literêre tekste en illustrasies is bestudeer. Klem is op karakter gelê: Die karakter in die illustrasie, die karakter in die teks en die gedrag van die karakter in beide media is ondersoek teen die agtergrond van oorlog, werk, spel en kommunikasie tussen die rasse. Die uitdrukking van emosies soos toegeneentheid of afkeer en die inhibering hiervan deur sosiale taboes, groepsverhoudinge en die gemeenskap, is ondersoek. Historiese, geografiese en kulturele outensiteit en die ideologiese boodskap van die tekste is kwalitatief bestudeer. Die voorkoms van attribute (stereotipes) soos toegeskryf aan 'n spesifieke ras is getabuleer in ' $n$ poging om bevindinge te kwantifiseer. Net die belangrikste bevindinge kan egter hier uitgelig word.

In die artikel word aangetoon dat verhale oor die "moorddadige swarte" besonder gewild was tot en met die jare vyftig en dat hierdie beeld ná 1960 verander het na uitbeeldings van die swart "terroris". Die swart "boef" is eweneens 'n populêre literêre karakter, so ook die beeld van die "infantiele swarte" teenoor die "alwetende blanke". Afrikaneretnosentrisme word ook bespreek. Swart as synde esteties en eties negatief sodat afkeer van sosiale of fisieke kontak met swartes as wenslik geag word in die literatuur, sal ook aangetoon word. Verhale waarin die "barbaarse swarte", die "komiese swarte" en die "dom swarte" en veral die "onderdanige swart bediende" figureer, word ook behandel.

Positiewe uitbeeldings van die swarte sluit in bewondering vir die swart kultuur en volksverhale en waardering vir sy kennis van die natuur en sy lewenswysheid. Die beeld van die dapper en onbaatsugtige swarte, die swart speelmaat op die plase, die liefdevol-moederlike/vaderlike swarte, die mooi swarte en die swarte as 'n komplekse, veelgefasetteerde individu word ook bespreek.

Daar sal aangetoon word dat Afrikaanse kinder- en jeugliteratuur wat sosiale kritiek bevat, skaars is en dat heelwat "positiewe" uitbeeldings in werklikheid positiewe stereotipes is en dus ook bevraagteken moet word. Die verskillende "sindrome", gebaseer op die Duitse model van

1 mel "swarte" word alle persone wal nie blank is nie, d.w.s. ook gekleurdes bedoel, tensy anders vermeld. 
Jörg Becker (1977), waaraan die Afrikaanse kinder- en jeugliteratuur mank gaan, sal bespreek word en twee uniek-Suid-Afrikaanse "sindrome" sal geïdentifiseer word. Laastens sal norme vir die Afrikaanse kinder- en jeugliteratuur in 'n veelrassige samelewing bespreek word.

\section{NEGATIEWE RASSE-ELEMENTE}

Die studie oor rasse-elemente in die Afrikaanse kinder- en jeugliteratuur toon aan dat dit nie vry te spreek is van negatiewe rasse-elemente of te wel rassisme nie. Die mees negatiewe voorbeelde kan egter in vroeër jare gevind word en die aantal verminder na 1960.

Gedurende die eerste helfte van die eeu was stories oor wit helde wat swart barbare beveg, baie gewild. Die lewe van die Voortrekkers is geidealiseer en die Engelse en die swartes is vir pionierskonflikte geblameer. Tot meer as $\mathbf{1 0 0}$ jaar nadat hierdie militêre botsings plaasgevind het, is aan kinders en jeugdiges gedetailleerde beskrywings van bloedige tonele gebied in ' $n$ poging om ' $n$ groeiende Afrikanernasionalisme te voed. Die Afrikaner het dit nodig gehad om sy geskiedenis te herleef met die doel om volkstrots aan te wakker en 'n gevoel van nasionale eenheid onder Afrikaners te ontwikkel. Die stories staan heeltemal onverskillig teenoor die lyding en gedagtes van die swartes wat in hierdie konflikte betrokke was, of die redes vir die botsings vanuit die oogpunt van die swarte.

In hierdie verband kan veral verwys word na Niko: die dromer : 'n kinderverhaal uit die dae van die Groot Trek deur Lulu Brewis (1935), Twee Voortrekkertjies deur P. Erasmus (1942), Kinders van die Voortrek deur M E R, veral die eerste uitgawe (1921), en Die Boggies van die Bosberg: grepe uit die lewe van 'n span piaasseuns deur J.J. Blom (1942).

Gewapende konflik tussen swart en wit, wat 'n minder gewilde tema tussen 1948 en 1960 geword het, maak sy herverskyning in Afrikaanse kinder- en jeuglektuur na 1960. "Terrorisme" op die grense van SuidAfrika sowel as stedelike "terrorisme" word 'n literêre tema. Die infiltreerders is meesal swart Kommuniste en hulle kollaborateure is blanke sendelinge, immigrante liberale en ander vreemdelinge. Die indruk word gewek dat die inboorlinge van die areas, bv. Namibië en Suid-Afrika, die "terroriste" nie ondersteun nie en dankbaar is vir die beskerming van die Suid-Afrikaanse regering wat betrokke is by die militêre stryd "vir die beswil van die swartes". 
In Drietal langs die Okavango deur B.R. Retief (1964), verseker Kaptein Verster sy manne dat die guerrilla-vegters op wie hulle moet vuur, nie "mense" is nie (p.49). H.S. van Blerk gebruik die Zimbabwese konflik as agtergrond vir sy boek, Faanman slaags met terroriste (1979), terwyl Cor Nortjé stedelike terrorisme uitbeeld in Tekkies en die sluipmoord (1979).

Afrikaanse kinder- en jeugliteraluur toon baie voorbeelde van swart, gekleurde, Maleise, Indiese, Japannese, Joodse en "donkerwit" skelms en misdadigers. Daar is ook blanke misdadigers wat meesal uitlanders is. Die wit Afrikaanse held wat dikwels ' $n$ jong, dapper en intelligente boer, soldaat of polisie-offisier is, uitoorlê hierdie boewe altyd, as 'n simbool van die goeie wat oor die bose seëvier.

In Na die storm deur Elizabeth Saunders (1939) kom twee gekleurde boewe voor wat 'n skat van 'n wit seun wil steel. In Kinders van die Kaliharie deur J.D. Olwagen (1930), is die dief 'n Maleierseuntjie wat twee wit kinders bedrieg. In die kortverhaal, Uilkraal se spook deur P. de Villiers uit Ons Maats-Jaarboek van 1948 kom daar twee skelms voor, nl. 'n oneerlike Jood en 'n "halfbloed" wat aangespreek word as, "Jou boesnot!" (p.40). In Berg van grafte deur Hermie Hendricks (1949) voorsien uitlanders onder aanvoering van 'n "ongebalanseerde" Hollander, gewere aan swartes in "Kafferland" (pp. 173-174). Verdere voorbeeide waarin swart boewe voorkom is Fanie, die jongspeurder van Doornbos deur Ben Arend (1955), Die heldin van Klipspruit deur G.S. Nienaber (1942) en 'n meer resente verhaal, Fransie, Sannie en die skaapdief (1977) deur Annalou Marais, waarin 'n swartman die kinders se hanslammetjie slag en eet. John van den Berg in Soois op die spoor (1957) en Soois op die plaas (1963) beeld ' $n$ Japannese boef en twee Indiër-boewe, onderskeidelik uit.

Etnosentrisme waar die Afrikanerkultuur as meerderwaardig in vergelyking met ander kulture gesien word, kom sterk na vore in die literatuur. Uitlanders word as bedenklike figure geteken, veral Engelssprekende vreemdelinge. Die idee dat die Afrikaner "die lig" na Afrika gebring het om die swarte van onkunde te verlos, word ook aangetref.

In hierdie verband kan veral verwys word na Oupa en sy kleindogters: 'n geskiedkundige roman (1939) van J.H.H. de Waal waarin 'n Australiër en 'n smous "met 'n onplesierige geel kleur", pp. 114-115 die boewe is en waarin die oupa die kinders waarsku teen "die skorrie-morrie, die 
skuim, die skelms van ander lande" (p. 153) en ook Sy wilskrag getoets (1939) van dieselfde outeur. In Die bende en die grot van Mamoesa (1957) deur Phil Olivier, klap die mense by die hutte hulle hande van vreugde omdat "die kleinbasies, die oubaas en die ounooi die lig gebring het". (p.128).

Die infantiele swarte wat die beskerming van sy deugsame, vrygewige en alwetende baas nodig het, kom algemeen voor in Afrikaanse kinderen jeugliteratuur. Hy is meesal 'n plaasarbeider, maklik beinvloedbaar soos ' $n$ kind, bygelowig en geheel en al afhanklik van sy baas wat al sy probleme vir hom oplos. In In die spelonk (1939) van J.H.H. de Waal word swartes beskryf as "kinders" wat maklik beinvloed kan word tot die "wreedste dade van geweld" (p.222). Die "bygelowige swarte" kom voor in Mietjie en die Tokkelossie (1956) van Sita (S.S. de Kock) waarin drie kinders ' $n$ hele stat verlos van 'n klein harige kluisenaar wat aangesien is vir 'n bose gees. Die wit deus-ex-machina wat die swarte van die bose moet verlos kom ook voor in Drie straatsangers in die Kongo (1943) van J.J. Groeneweg.

Negatiewe opvattings oor die estetika en etiek van swartheid word uitgedruk. "Europese" norme (in Suid-Afrikaanse sin) as 'n maatstaf vir skoonheid word gebruik. Die idee dat wit gelykstaan aan die goeie en swart gelykstaan aan die bose kan telkens gevind word. Die "witheid" van 'n persoon se hart word gesien as afgesien van sy velkleur maar 'n element van rassisme is tog duidelik waarneembaar aangesien die innerlike deug van 'n swarte uitgebeeld word asof dit op een of ander wyse in kontradiksie tot sy swart velkleur staan.

In Gwennie Barneveld (1924) van G.R. von Wielligh kom die swartmense van oral om Gwennie te kom bewonder en wil van haar weet waarom witmense "wat so mooi is", hulle "liggame bedek met klere", terwyl "ons Kaffers wat so swart en lelik is, kaal rondloop?" (p.136). In die fantasieverhaal, Die swart babatije (Ons Kinderjaarbook Nr. 7, 1948) deur Ela Spence, kry 'n kaboutergesin 'n swart baba i.p.v. 'n witte tot groot konsternasie van die hele gemeenskap. Ouma Weetalles verwerp egter die idee van 'n swart baba as "belaglik. Daar was nog nooit 'n swart baba in Kabouterland nie en ou Dr. Ooievaar het nie een swart baba in sy hospitaal nie" (p. 43). Hierop was sy die skoorsteenroet van die baba af waarop die verheugde gesin hul "spierwit baba met sy pragtige glimlag en helderblou oë", (p.44) omhels. Verwysings na die "wit hart" of "wit inbors" van swartes, kom voor in Janette: 'n dogter wat geen dame 
wou word nie (1939:19) deur Sita, en Die eksentrieke Essie (1939:74) deur J.H.H. de Waal. In 'n Hennetjie met Kuikens (1971:36) van Alba Bouwer word daar verwys na die "wit harte" van blankes. 'n Kortverhaal deur Ela Spence in Kinderjaarboek Nr. 4 (1945) getiteld, Die swart kaboutertjies, beeld 'n "rassekonflik" tussen swart en wit kabouters uit waarin swart as boos en wit as edel voorgestel word. Die leier van die swart kabouters se naam is "Kroesiekop".

Afkeer van sosiale of fisieke kontak met swartes word dikwels aangetref. Gedragsreëls om sosiale afstand in die huishouding te verseker word uitgespel. Aanspreekvorme word aan kinders gekommunikeer deur die literatuur, om 'n verskil in sosiale status aan te dui. Familiariteit van swartes met blankes word in Afrikaanse kinder- en jeuglektuur gestraf.

In Aanstap! Voorwaarts (1958) deur H.W. van der Merwe, betig 'n ouma haar kleindogter as volg: "Jy moenie met die swartgoed so te kere gaan nie. Netnou dink hulle jy is hulle maat. Kaffers moet op hulle plek gehou word anders word hulle parmantig en eie met ons" (p.1). In Doea gaan tronk toe (1945) deur L.J. Boerop waag twee swart bediendes dit in 'n krisissituasie "tot in die middel van die sitkamer maar die baas jaag hulle nie terug nie en die nooi jaag hulle ook nie terug nie ... Nou eers sien die baas dat die Kaffers by die tafel staan, maar hy sal nie vanaand met hulle raas nie" (p.28). In Kinders van die Kaliharie (1930) deur J.J. Olwagen word 'n voorbarige Maleierseun wat probeer om op gelyke voet met twee wit kinders te verkeer, as 'n bedrieër ontmasker en swaar gestraf. In Janette (1939) deur Sita, dreig Janette om "die meid" te vermoor want "hierdie baster ding" sê sommer vir haar "jy" en "jou" (pp. 44-45). J.D. Seymore in Outa Danster en Aia Martha (1931) berig dat die twee bejaarde swartes die kinders gedurig daaraan herinner het dat hulle as blanke kinders "hoër wesens as hulle (die swartes) is" (p.4).

Afkeer van sosiale kontak met swartes in die literatuur impliseer soms dat swartes se liggaamshigiëne gebrekkig sou wees. In Lank lewe die Bushies (1946) van die broers Hendrik en Fritz von Hörsten, betree 'n ondeunde wit seun die kombuis met 'n sigaretdosie waarin hy 'n gat gemaak waardeur hy sy eie swartgesmeerde vinger gesteek het. Hy wil van sy ouers weet of hulle "die gebalsemde vinger van 'n kaffermeid" (p.26) wil sien. Sy ma se reaksie is as volg: "Voertsek Johannes! Ga! hoe stink so 'n maaifoedie se kaffermeid! ... O vadertjie toggie, hoe naar maak so 'n konfoeste meid my tog nie" (pp. 27-28). Sy pa se reaksie is: "Sies!" ... dit stink die pure kaffer. Ga, die reuk is al die hele huis 
vol! Vat nou dadelik uit die gemors, jy verpes ons!" (p.28).

Seksuele verhoudings tussen swart en wit word uitgebeeld as tussen swartes en hoofsaaklik wit vreemdelinge. Dit word duidelik gestel dat 'n Afrikander nooit so "laag sal daal" nie. Hierdie blankes in Afrikaanse jeugliteratuur is altyd die misdadigers. Swartes wat toenadering soek, word met die grootste minagting deur "ware Afrikaners" behandel.

In hierdie verband kan De Grensbewoners (1920) van D'Arbez bestudeer word, waarin daar wel drie Afrikaners voorkom wat saam met swart vroue leef maar wat as boewe en "smeerlappe" uitgebeeld word (p. 123). In Woorde en dade (1939) van J.H.H. de Waal verwerp 'n blanke meisie die loenaderings van ' $n$ swartman met minagting. G.H. Franz in Rabodutu die eensame (1945) vertel die onoortuigende verhaal van die bemoeienisse van swartes om 'n wit vrou te soek vir die opgeskote seun van hulle oorlede "baas" en "nooi" uit vrees dat ondertrouery mag plaasvind wat tot die ontstaan van "mensmuile" sal lei. Swartes word dus in hierdie verhaal gebruik om volgens ' $n$ wit ideologie op te tree. Dit word egter so gestel as sou die swart gemeenskap ernstig besorg wees oor die gevaar van bloedvermenging.

Daar is talle voorbeelde in die literatuur waar swartes uitgebeeld word as barbare, waar hulle kaal rondloop, rou vleis en ander grusaamhede eet, waar hulle gruwelike dinge doen wanneer hulle bedwelmd is en 'n barbaarse eetlus het. Daar is karikature in illustrasiewerk waar distorsie van 'n eienskap plaasvind om die swarte belaglik te laat lyk. Die indruk word dikwels gewek dat die beskrywing eg is en nie 'n oordrywing van die realiteit nie. Swartes word in verslete klere uitgebeeld met dik lippe, bobbejaanagtige gelaatstrekke, boepense, geen tande, ens. Hulle gesigsuitdrukkings wissel meesal tussen verwardheid en onnoselheid. Die idee dat swartes nie so intelligent is soos blankes nie, word ook gekommunikeer.

In Die Krismiskinders (1933) van C.J. Langenhoven word Boesmans uitgebeeld wat rou vleis eet, bier drink en dagga rook totdat hulle "dol" is (p.353). In Vier Kinderstories (1930) deur J.D. Olwagen, kom 'n kortverhaal voor, getiteld $\mathrm{Ou}$ Geelbooi waarin 'n gekleurde met nege tone, sy kleintoontjie wat hy in 'n ongeluk verloor hel, insluk uit vrees dat dit by hom sal spook. In Vakansie op die plaas, 'n kortverhaal in Ons MaatsJaarboek (1948), kom 'n illustrasie voor wat as 'n voorbeeld van soömorfisme beskou kan word (p.84): Terwyl twee wit seuns in netjiese 
baaibroeke gekleed is, lyk die nakende bruin seun, Boesman, sprekend op 'n potsierlike padda soos hy in die water duik. Die verhaal is deur die Von Hörsten broers geskryf maar die illustreerder is onbekend. Die samesteller is Sarel Marais. Boerneef het 'n voorliefde om "humoristiese" voorname vir plaasarbeiders te kies waardeur een of ander persoonlike eienskap gekarikaturiseer word. In Pensie (1938), Van my kinderdae (1939) en Vlettervlie en Koesnaatjie (1948, 2de uitgawe) kom name soos Ou Gert Perdebek, Ou Knopkies, Piet Hardnek, Hendrik Sopbek, Gert Varkspek alias Gert Lekkervreet, Knopneus Diklippe, Mierka Maerskene en Doekvoet voor. Die gewaande onnoselheid van die swarte kom ook in genoemde werke voor, veral in Van my kinderdae (pp. 2,21 ) asook in Boerseun bo! of die handjie op die klip van W.F. Loots (1961:18). In M.H. Theunissen se Drosters: twee boeiende verhale vir kinders (1932:35) word twyfel uitgespreek of 'n swarte 'n mens is: "'Wat beweeg daar oorkant?' vra Martin. Jan tuur by die rivier op. 'Lyk my na 'n - 'n Kaffer of 'n mens?'"

"Humoristiese" stories waarin blankes misbruik maak van die ekonomiese en sosiale verwondbaarheid van die ondergeskikte swarte en waarin swartes weens hulle gewaande bygelowigheid die skyf word van wit kinders en selfs volwassenes se spookspeletjies kom vry algemeen voor in die Afrikaanse kinder- en jeugliteratuur voor 1960.

In hierdie verband kan Vlettervlie en Koesnaatjie (1948) van Boerneef (pp.26-30) Ou Geelbooi (1930:24-28) deur J.D. Olwagen en Kaskenades en wederwaardighede verhaaltiies vir die jongspan (1943:46-54) deur H.F. Koch bestudeer word. Die idee dat swartes so dom is dat hulle kinders se spookspeletjies ernstig sal opneem, toon 'n betekenisvolle naiwiteit by sommige skrywers.

Ten slotte, is daar sommige Afrikaanse kinder- en jeugboeke wat aantoon dat wit kinders 'n sekere graad van parmantigheid jeens swartes toegelaat word; swart volwassenes word verwag om selfs persoonlike beledigings van wit kinders te verduur. Enige reaksie op beledigings kan ernstige gevolge hê soos bv. liggaamlike straf van die swart bediende of selfs ontslag.

Die jeugboek, Janette (1939) deur Sita, het as sentrale tema die konflik tussen ' $n$ wit tienermeisie en 'n gekleurde bediende. Janette wat op die plaas gewoond is aan onderdanige swart arbeiders, kom in die stad by familie woon. Sy bots spoedig met die selfversekerde "geel Kaapse 
meid" (p.34) wat weier om 'n "meid" genoem te word. In een van hulle menige woordewisselings, sê Janette die volgende: "Kyk hier, jou halfnaat van 'n kamsketel. In my hele lewe, het 'n ellendige kaffermeid nog nie so met my gepraat nie! Jy kan kies of ek jou moet verwurg en of ek jou nek moet breek" (p.37). In 'n ander toneel spreek sy Grace as volg aan: "Haai, jou halfnaat van 'n kaffermeid, jou yslike smerige hekel ..." (p.53). Grace word ten slotte ontmasker as 'n gemene dief, ontslaan en haar plek gevul met ' $n$ wit weesmeisie, met wie Janette onmiddellik bevriend raak "omdat ek 'n mens is net soos sy" (1937:124). Die boodskap is dus dat wit bediendes soos gelykes behandel moet word en swart bediendes soos minderwaardiges en ondergeskiktes. Janette het in 1937 verskyn en is in 1939, 1947, 1950, 1953 en 1957 herdruk. In 1959 is dit bekroon met die Scheepers-prys vir Jeugliteratuur van die S A Akademie vir Wetenskap en Kuns. In 1963 en 1972 het 'n tweede en 'n derde uitgawe verskyn waarin die kwetsende taal grootliks geskrap is. Die rassistiese boodskap van die verhaal bly egter onveranderd.

Om op te som: die volgende bevooroordeelde assumpsies en stereotipes is gevind: die moorddadige swarte, die barbaarse swarte, die kriminele/immorele swarte, die bygelowige swarte, die dom swarte, die lelike swarte, die komiese swarte, die infantiel/hulpelose swarte en die swart bediende teenoor wie sosiale/fisieke afstand bewaar moet word.

Daar is bewyse dat sekere stereotipes gedurende sekere historiese tydperke oorheers het en ook dat die hoeveelheid negatiewe stereotipes groter is gedurende sekere periodes as in ander. 'n Grafiese voorstelling van die historiese distribusie van die agt mees frekwente stereotipes wat in die studie aangetref is, kan nageslaan word in Tötemeyer, A-J, The racial element in Afrikaans children's and youth literature, D Phil. University of Stellenbosch, 1984 (ongepubliseerde proefskrif).

\section{POSITIEWE RASSE-ELEMENTE}

Gelukkig is alle rasse-elemente wat gevind is nie negatief nie. Die studie het bevind dat daar verskeie skrywers van Afrikaanse kinder- en jeuglektuur is wat 'n opregte bewondering vir en toegeneentheid jeens swartes het. Hierdie skrywers se spesiale kennis van die kultuur en gebruike van swartes stel hulle in staat om hoogs informatiewe en waarderende literatuur vir kinders en jeugdiges te skryf. Hierdie outeurs probeer wit kinders inlig oor swart kulture in 'n poging om 'n beter begrip 
vir swartes te bevorder en ook om 'n bewondering en waardering vir hulle en hul kultuur te kweek. Kinders word ook onder die besef gebring dat elkeen die reg het om trots te wees op sy erfgoed. Die gebruike van die swartes word nie as rariteite daargestel nie maar met opregte entoesiasme.

Skrywers in hierdie kategorie is G.R. von Wielligh met sy Boesmanstories (1922), J.J. Groeneweg met Waar die doringbome fluister (1925), M E R met Karlien en Kandas (1934, 3de uitgawe 1975), Dorothea MöllerMalan met Tshikobani, seun van die Senzi (1961) en J.P. Fourie met Malupi (1970).

Daar is ook gevind dat daar 'n groot aantal blanke skrywers is wat dankbaar is vir die verryking wat swart volksverhale hulle besorg het. Dit het so baie vir hulle as kinders beteken, dat hulle genoop voel om die stories op te teken vir toekomstige geslagte. Hierdie skrywers, samestellers en oorvertellers wat glo dat swart legendes, fabels, mites en sprokies 'n kosbare bron van verryking vir alle kinders in Afrika is, ongeag ras, het 'n groot bydrae gelewer om mondelinge literatuur te bewaar wat andersins verlore mag gegaan het.

G.R. von Wielligh, in sy inleiding tot Dierestories (1918) en Boesmanstories getuig van die groot invloed wat die stories van Sanen Khoikoi-vertellers op hom as kind gehad het; net so ook D.J. Seymore in Outa Danster en Aia Martha (1931). Eugène N. Marais lewer 'n unieke bydrae met sy Dwaalstories en ander vertellings (1927), so ook K.L. en A.O. Vaughan wat so vroeg as 1910, Ou Hendrik z'n stories in Londen laat publiseer, met as bekendste verhaal, Hoe het kwam dat baviaan een kink in zijn staart heeft. C.L. Leipoldt in Kampstories (1924) en veral I.D. du Plessis in Uit die Slamse buurt (1939) en Die gevleueide perd en ander Kaapse verhale (1943) lewer 'n bydrae om Maleierverhale op te teken. Ander oorvertellers wat verdienstelike werk in hierdie opsig gelewer het, is Minnie Postma (Basoetoverhale), J. Bruwer (o.a. verhale uit Sentraal-Afrika), Anne de Ville (Madagaskar-verhale), Aletta Lübbe (o.a. verhale uit Nigerië, Soedan, Malawi, Lesotho, Swaziland), Helene de Villiers (Sentraal-Afrika asook Pondoland), Marie Opperman en Pieter Erasmus (Zoeloeverhale), asook P.W. Grobbelaar wie se bundel Die mooiste Afrikaanse sprokies (1968) met die C.P. Hoogenhout-Medalje bekroon is.

Daar is voorts Afrikaanse kinder- en jeugboeke gevind waarin die 
wysheid van swartmense geloof word en waarin dit duidelik gestel word dat blankes van hulle kan leer. Weens die swarte se kennis van plante en diere, laat sommige skrywers kom optree as die leermeester en adviseur van blankes.

In hierdie verband kan verwys word na P.J. Schoeman se Op die klein spoortjies (1945), Fanie se veldskooldae (1948) en Fanie se vuurdoop (1960), Klein Trekboertijes (1944) deur Jeannette Nel en Manela die olifantbul (1981) deur W.A. Hickey.

Skrywers betuig dikwels dankbaarheid teenoor die swarte vir sy/haar onbaatsugtigheid, diensbaarheid en dapperheid en toon sensitiwiteit vir sy gevoelens en emosies. In Kinders van die grens: 'n verhaal vir kinders (1944) deur E. Rautenbach, help 'n ou San 'n blanke gesin om te oorleef in die wildernis. Hulle hartseer wanneer hy hulle na hul aankoms op hul plaas moet verlaat, getuig van opregte toegeneentheid en dankbaarheid. In Benman van die Bosveld (1980) van Sanet te Groen, maak 'n klein seuntjie sy spaarbussie leeg uit dankbaarheid teenoor 'n swartman wat sy hondjie se lewe gered het. In 1951 skryf Jurgen Smith twee Kersfeesstories, getiteld Amakeia, waarin Amakeia se heldedaad beskryf word. Daar word vertel dat die blanke vader sy baba sowel as die getroue bediende, Amakeia, wat albei deur die Xhosas vermoor is, aan weerskante van sy gestorwe vrou in die familiekerkhof begrawe het (p.14) en melding word gemaak dat Amakeia en die wit baba saam in die Hiernamaals verkeer (p.15).

Vriendskap en pret op die plase waar interrassige sosiale kontak nog moontlik is, is 'n gewilde literêre tema. Kinderpret, ondeundhede en humor, insluitende kaal swemmery tussen jong seuns van verskillende velkleure kom vry algemeen voor. In Booi en sy maats (1948) deur Ans, Die speurders van Waterval (1979) deur I.D. Lamprecht en Die Palomino (1980) deur Johann Becker kom interrassige swemmery voor. Wanneer die publikasiedatums van hierdie werke beskou word kan die afleiding gemaak word dat hierdie tema nie aan gewildheid verloor het nie. Interrassige pret op die plase kom voor in 'n Hennetjie met kuikens (1971) en Stories van Rivierplaas (1955) van Alba Bouwer. In laasgenoemde boek ruil twee wit dogtertjies en twee swart dogtertjies klere: die swart kinders trek die rokkies en broekies van Alie en Lulu aan en die wit kinders trek die kralebandjies en ringe van Sanna en klein-Melitie aan; hierop leer die swart kinders die wit kinders hoe om die askoek te dans (pp. 12-13). Verdere voorbeelde van literatuur waarin interrassige vriend- 
skappe voorkom is Koert se tarentaal (1978) deur Elsabé Steenberg, Saam met Lonkies (1945) deur Ren Bosman, Moriti: 'n jeugverhaal deur Earl Martin (1978), Wit Oemfaan (1965) deur F.A. Venter, In voetpad se kloof (1970) deur P.H. Nortjé, Ngonyama keer terug; die avonture van Kristof en die slaweseun, Kobo (1978) van Nickey van Schalkwyk, Wannelas van Hester Heese en 'n Tuiste vir Bitis (1980) deur Frede Linde waarvoor sy die Scheepers-prys ontvang.

Die skeiding van plaasvriende deur die beleid van opvoedkundige segregasie in 'n literêre tema wat as 'n treurige maar onafwendbare ontwikkeling aanvaar word. In hierdie verband kan verwys word na ' $n$ Hennetjie met kuikens en Tier se tier (1978) deur Louw Combrink.

Daar is ruim bewyse van opregte toegeneentheid tussen rasse en betrokkenheid by die welsyn en gevoelens van mekaar. Uitbeeldings van die dood van, en gevoelens van verlies oor lede van 'n ander ras, kom dikwels voor. Daar word ook soms krisisse daargestel wat sosiale afstand verklein en toenadering tussen die rasse meebring.

Hier kan verwys word na Outa Fransie en ander verhale (1938) deur Sita, waar die smart van ' $n$ blanke gesin by die dood van ' $n$ bejaarde plaasarbeider uitgebeeld word. In Stinkie (1943) getuig Cecil van der Spuy van die opregte liefde wat hy as weeskind vir ou Piet gekoester het (p.21). Die swarte as plaasvervanger vir een of albei ouers van wit weeskinders kom telkens voor in Afrikaanse kinder- en jeugliteratuur, bv. ook in Chrissie en Joey (1925) deur Hettie Cillié. 'n Spesiale gevoel van toegeneentheid tussen 'n swart volwassene en 'n blanke kind kom voorts voor in Stories van Rivierplaas (1955), Nuwe stories van Rivierplaas (1956) en Katrientjie van Keerweder (1961) van Alba Bouwer. Hierdie nostalgiese verhale is meesal gebaseer op herinneringe uit die kindertyd van die outeur op 'n Vrystaatse plaas. Dieselfde verhouding kom voor in Dirkie van Driekuil (1966) wat afspeel op 'n Bolandse plaas. In Wannelas van Hester Heese veroorsaak 'n krisissituasie dat 'n swart en wit seuntjie saam onder ' $n$ kombers by ' $n$ beseerde moet waak terwyl hulle styf teen mekaar druk vir "warmte en troos" p.18.

Die aantal outeurs soos Alba Bouwer wat uit 'n landelike agtergrond kan skryf en veral diegene wat voor 1948 gebore is, waarna die grootste aantal diskriminerende wette gepromulgeer is, is vinnig aan die verminder. Jonger en meesal stedelike outeurs as produkte van 'n gesegregeerde politieke sisteem, het feitlik geen sosiale kontak met 
swartes nie en ook geen jeugervarings van noue interaksie tussen rasse nie. Dit skep dus vir hulle 'n probleem om hierdie gaping in hulle ervaring te oorbrug. Sommige van hierdie skrywers het egter desnieteenstaande daarin geslaag om verhale met swart hoofkarakters te skep met persoonlikhede wat baie faselte het. Die leser bly onbewus daarvan dat hier 'n blanke skrywer aan die woord is en die feit dat die karakters swart is, word heeltemal onbelangrik in die lig van hulle komplekse en universele menslike nature. Sulke boeke kan rassevooroordeel teëwerk omdat die leser in staat gestel word om homself heeltemal te identifiseer met die gevoelens van die hoofkarakters.

'n Hele aantal literêr-verdienstelike werke val in hierdie kategorie, o.a. Skankwan van die duine (1930) deur die Hobson-broers, Abdoltjie (1958) deur Alba Bouwer, Kind van die duine (1963) en Vonk, vondeling van die duine (1964) deur Jan J. van der Post, Snoet-Alleen (1964) en Die singende gras (1973) waarvoor Freda Linde die C.P. Hoogenhout-Medalje en Scheepers-prys onderskeidelik ontvang, Loekie die rondlopertjie (1966), Ek en jy, Grootbroer (1970) en Die geluid van wakker (1981) deur Hester Heese, Salmaklak: 'n legende van die Vaalrivier (1971) deur Ben Venter, Molisana, die seun wat die klei-osse maak (1972), Wat maak jy, Hektor? '(1974) wat met die C.P. Hoogenhout-medalje bekroon is, Luister, Lefa (1976), Die aarbeimense (1980) en Al Everest se voëls (1984) deur Rona Rupert, Fesito gaan mark toe (1979) en Kaninu se geheim (1979), twee bundels kortverhale met Oos-Afrikaanse kinders as hoofkarakters deur Cicely van Straten en ' $n$ Pakkie mieliepitte (1984) deur Maretha Maartens. Laastens verdien die kortverhaal, Oupa Kyken deur Alba Bouwer in die versameling Storiehuis woordpaleis (1979) spesiale vermelding.

Literatuur met beide swart en wit hoofkarakters blyk 'n moeiliker onderneming te wees. Die skrywers moet of ' $n$ wêreld van rasseharmonie of rassekonflik uitbeeld. Die meeste outeurs kies die Heile Welt van utopiese rasseharmonie selfs al moet die realiteit gemanipuleer word. Dit blyk dat die plaas of die wildernis die enigste agtergrond is waarteen harmonieuse interrassige vriendskappe aangebied kan word. Die stedelike milieu in Suid-Afrika leen sigself weens die gesegregeerde woongebiede vir verskillende rasse, nie baie goed tot noue interrassige kontak nie.

Interrassige vriendskappe wat uitgebeeld word is meesal tussen seuns; selde tussen dogters en nooit tussen seuns en dogters van verskillende 
rasse nie. Slegs drie jeugboeke kon gevind word wat interrassige konflik tussen hoofkarakters beval, nl. Wit oemfaan (1965) van F.A. Venter, Korrel en Kuif (1975) deur Elsabé Steenberg en Matoli (1978) deur Etienne van Heerden waarin die tema van interrassige seksuele attraksie voorkom wat gepaard gaan met akute skuldgevoelens. In Sersant Barodien, Kaapse Korps (1977) van Dan Sleigh, kom sosiale kritiek voor asook in Korrel en Kuif. Laastens verdien Stanley Bekker en die boikot (1980) deur John Miles spesiale vermelding. Die verhaal handel oor die skoleboikot in Johannesburg in 1980 en bevat kritiek op die SuidAfrikaanse politieke bestel, veral op groepsgebiede, minderwaardige onderwys vir swartes, die gebrek aan stemreg vir swartes, rassediskriminasie en die behandeling van swartes in Suid-Afrikaanse tronke. Dit is met publikasie besitsverbode verklaar, twee jaar later is die besitsverbod opgehef en is dit slegs as verbode verklaar en in 1985 is die verbod heeltemal opgehef maar eers nadat daar geappelleer is.

Om op te som: die volgende positiewe beelde van die swarte in die Afrikaanse kinder-en jeugliteratuur is gevind: die gekultiveerde swarte; die edel en dapper swarte; die ingeligte, wyse, intelligente, betroubare swarte; die liefdevolle en vriendelike swarte (insluitende interrassige toegeneentheid en betrokkenheid); die veronregte swarte; die mooi swarte (insluitende interrassige seksuele attraksie) en die swarte as komplekse, multi-dimensionele individu.

'n Grafiese voorstelling van die historiese distribusie van negatiewe en positiewe beelde van swartes in Afrikaanse kinder- en jeugliteratuur toon 'n amper volmaakte "skêr"-formaat met die kruisingslyn op 1957 toe die hoë persentasie negatiewe beelde vinnig begin verminder het van $69 \%$ in 1940 tot $13 \%$ in 1982. Die aanvanklik lae persentasie positiewe beelde, met die laagste punt van $31 \%$ weer eens in 1940, het ooreenkomstig skerp gestyg tot $87 \%$ in 1982 .

Dit sou egter onwys wees om valse optimisme oor die huidige bevinding van die studie aan die dag te lê. Bale voorbeelde wat as "positief" geklassifiseer is in werklikheid positiewe stereotipes. Om die swarte slegs as "deugsaam", "dapper", "liefderik", "vriendelik", "hulpvaardig" ens. uit te beeld, is om die veelgefasetteerde persoonlikheid van die swarte as volle individu te ontken. 


\section{Sindrome}

Sommige skrywers maak hulle ook skuldig aan die "vermydingsindroom" deurdat hulle probeer om rasseprobleme te verbloem; want as iets nie as problematies daargestel word nie, het dit ook nie 'n oplossing nodig nie.

'n Verdere sindroom wat verwant is aan die "verwyderingsindroom" is die "harmoniseringsindroom" waar probleme nie heeltemal verswyg word nie, maar waar hulle "versag" word. Omdat konflikte nie altyd heeltemal vermy kan word nie, word gepoog om hulle op te los deur middel van "simpatie" vir die swart karakter of ook deur onwaarskynlike kitsoplossings.

Die Duitse navorser Jörg Becker (1977:537-8) waarsku teen "simpatie" vir die swarte omdat dit die dwang van dankbaarheid op hom projekteer. Simpatie kan paternalisties wees; net die gegoede kan aalmoese bekostig en net die minderbevoorregte het nodig om dit te ontvang. In Afrikaanse kinderliteratuur is die swarte meesal die ontvanger.

Verdere "sindrome" wat deur Becker gedurende sy studie van rassisme in Duitse kinder- en jeugliteratuur geisoleer is en wat ook in Afrikaanse kinder- en jeugliteratuur gevind is, is die "biologiese sindroom" waar die fisieke eienskappe van swartes op 'n ongunstige wyse gekontrasteer word met die fisieke eienskappe van blankes en die "avontuursindroom" waar die swarte slegs uitgebeeld word as 'n ondergeskikte en marginale karakter. Hy vorm deel van die agtergrond waarteen die blanke hoofkarakters hulle avonture beleef.

Die "gebreksindroom" word gemanifesteer deur literatuur waar die sosiale probleme van swartes soos armoede, ongeletterdheid, bygelowigheid, misdaad en alkoholisme gestel word al sou die swarte self daarvoor te blameer wees. Die onderliggende oorsake van hierdie probleme en die feit dat die hele politieke bostruktuur oor honderde jare gevestig is om o.a. die opwaartse sosiale mobiliteit van swartes te verhoed, word verswyg. Die swarte word uitgebeeld as die "white man's burden" wat deur die blanke "gedra" en "ondersteun" moet word tot tyd en wyl hy sy "gebreke" oorkom het indien ooit.

'n Verdere "sindroom" wat voorgekom het is die "geweldsindroom" waar die swarte geblameer word vir rassebotsings. 
Die "dehistoriseringsindroom" wat historiese perspektiewe vanuit die blanke se oogpunt daarstel, en dus die swart kind van sy eie geskiedenis vervreem, kom vry algemeen voor in Afrikaanse kinder- en jeugliteratuur.

Twee tipies Suid-Afrikaanse "sindrome" wat nie in ander taalgebiede buite Suid-Afrika voorkom nie, is die "liefde-haat sindroom" en die "apartheidsindroom". Dit was opvallend dat beide positiewe en negatiewe beelde van swartes soms in een boek voorgekom het. Skrywers wat in hierdie verband genoem kan word is D'Arbez, J.H.H. de Waal, G.R. von Wielligh, Boerneef en Sita. Die feit dat sommige skrywers die swarte as mens, vriend en speelmaat dikwels as bediende liefhet, maar hom ook haat die oomblik wanneer hy met die blanke meeding as sy gelyke, is dikwels 'n manifestasie van vrees. "Liefde" en "vriendskap" is dikwels net moontlik solank die swarte sy "plek ken". Die "apartheidsindroom" kom sterk na vore deur die kritieklose aanvaarding van die verbreking van interrassige vriendskappe deur opvoedkundige, sosiale en ekonomiese segregasie, die plasing van interrassige vriendskappe in landelike omgewings alleenlik, of die afwesigheid van interrassige vriendskappe in stedelike gebiede en die taboe wat daar bestaan op interrassige-intergeslagtelike kontakte tot die punt dat ' $n$ wit seun nie eens met 'n swart meisie mag praat nie.

In baie gevalle is negatiewe stereotipes eenvoudig vervang deur positiewe stereotipes. Swartes word in 1982 nog steeds uitgebeeld as hande-arbeiders of huisbediendes. Die enigste twee beroepe waartoe die swarte in die literatuur in staat is, is die van die onderwyser en die predikant. Uitvoerende poste in die verhale word gereserveer vir die blanke wat altyd die werkgewer van die swarte is. Die ideologiese motivering wat die toekenning van sekere rolle vir swartes en vir blankes onderlê, is die perpetuering van die status quo en die inhibering van sosiale verandering.

Aan die werklike positiewe kant moet egter genoem word dat sedert 1950 dat al hoe minder aanvaarbaar word om beledigende literêre beelde van swartes aan te bied. Vernederende aanspreekvorme en verwysings word vermy en die aanbieding van die swarte as ' $n$ veelgefasetteerde, volle individu neem vinnig toe. Afrikaanse jeugliteratuur met 'n mate van sosiale kritiek het sy verskyning gemaak, alhoewel die ontvangs tot dusver koel was. 


\section{AANBEVELINGS EN SLOTWOORD}

Die belangrikste bevindings van die studie is samevattend dus dat literêre uitbeeldings van die swarte in die Afrikaanse kinder- en jeugliteratuur oorwegend negatief was tot die vyftiger jare toe en dat hierdie tendens sedertdien verander het na 'n meer positiewe literêre uitbeelding. Aangesien sommige positiewe uitbeeldings egter positiewe stereotipes is en die Afrikaanse kinder- en jeugliteratuur in sy aanbieding van die swarte as literêre karakter boonop aan verskeie "sindrome" ly, is daar min rede vir optimisme. Die uitbeelding van die swarte, in vir die blanke ideologies-aanvaarbare sosiale "rolle", kan as 'n vorm van bedekte rassisme beskou word. In oorsese studies word daar veral op hierdie vorm van "covert racism" gewys wat as meer subtiel en gevaarlik as "overt racism" beskou word (cf. Banfield, B in Preiswerk, R ed., The slant of the pen, 1980:14).

$\mathrm{Na}$ aanleiding van die navorsing wat daar in Wes-Duitsland (cf. Becker 1977, Benzing 1978 en Grosse-Oetringhaus 1978), Brittanje (cf. Dixon 1977 en Milner 1975), die V S A (cf. Brodrick 1973 en Sadker 1977), Holland (cf. Redmond 1980), Puerto Rico (cf. Nieves-Falcón in Preiswerk, 1980) en Brazilië (cf. Rosemberg 1980) op die gebied van rassisme in die kinder- en jeugliteratuur gedoen is, het verskeie instansies en individue riglyne opgestel vir die uitkenning van rassisme in die literatuur Die mees omvangryke lys is in 1978 opgestel gedurende ' $n$ werkswinkel oor rassisme wat in Arnoldshain Wes-Duitsland gehou is onder die vleuels van die Wêreldraad van Kerke. Die hoofpunte van die lys, getiteld, "Criteria for the evaluation of racism in textbooks and children's lilerature" (cf. Children's Books Bulletin, 1979, 1 (June): 5-8) kan as volg opgesom word:

* Verhoudings: Beklee blankes in die verhale altyd 'n leidende of outoriteitsposisie teenoor swartes wat bloot in ondersteunende rolle fungeer of as randfigure en toeskouers optree? Is blankes paternalisties, vrygewig en goedgunstig teenoor swart karakters? Is swartmense naamloos, vanloos of sonder persoonlikheid?

" Swart hoofkarakters: Word swart hoofkarakters bewonder vir dieselfde eienskappe as waarvoor hulle wit eweknieë bewonder word, of omdat wat hulle gedoen het, witmense bevoordeel het? Wie se belange dien ' $n$ bepaalde figuur? Moet ' $n$ swarte uitstaande kwaliteite besit om aanvaar te word? 
* Lewensstyle: Word swartes in hulle sosiale bestel ongunstig gekontrasteer met die "wit norm", of word insig verleen in 'n ander lewensstyl terwyl positiewe aspekte daarvan soos die solidariteit van die groot familie beklemtoon word?

* Sosio-politieke en -ekonomiese perspektief: Hoe word hierdie aspekte rakende die swarte benader? Word swartes uitgebeeld as "die probleem"? Word armoede as onvermydelik aanvaar of word sy oorsake belig? Watter oplossings word aangebied? Wat leer die leser i.v.m. hierdie probleme en wat word doelbewus verswyg?

* Historiese perspektief: Wie word geblameer vir gewapende konflik tussen swart en wit? Word die ware griewe onderliggend aan dade van aggressie verdraai, geignoreer, toegesmeer of onpartydig uiteengesit? Word die uitwerking van neerlae op die groepe wat verslaan is bespreek of uitgelaat?

* Illustrasies: Word swartes gestereotipeer met dik lippe, wit tande, kinderlike, dom gesigsuitdrukkings? Word swartes aan die ander kant hul eie identiteit ontsê deurdat hulle net soos blankes lyk behalwe vir 'n effense kleurtint? Lyk swartes almal eenders of word hulle as individue geteken? Wie doen wat? Wie gee bevele? Word swartes ook geteken in leierskaps- of aksierolle?

* Taal: Uiter swartes gebroke taal of beperkte taal in vergelyking met wit karakters in die verhale? Is hulle meesal swygsaam of stom? Word gelaaide adjektiewe soos "barbaars", "primitief" of "agterlik" gebruik. "Hurk" swartes terwyl blankes "sit", "slurp" swartes hulle koffie terwyl blankes hul koffie "drink"?

* Moontlike uitwerking op die leser: Versterk die boek 'n positiewe assosiasie met die kleur wit en 'n negatiewe assosiasie met die kleur swart? Is daar enige karakter in 'n bepaalde storie met wie 'n swart kind geredelik kan identifiseer? Aan die ander kant, word die beeld van die blanke in die storie afgebreek in 'n poging om die swarte te idealiseer? Word skuldgevoelens moontlik by die blanke kind gewek wat hy/sy nie kan hanteer nie?

Wat veral kortkom in die Afrikaanse kinder- en jeugliteratuur is die 
uitbeelding van die swarte as 'n aktiewe en onafhanklike mens en nie as die objek van wit paternalisme en goedgunstigheid nie. Ten einde swart en bruin kinders in staat te stel om geredeliker met literêre karakters te identifiseer, behoort klem gelê te word op die swarte in ander rolle as bloot die arbeider of bediende. Benewens die swart onderwyser en predikant behoort die swart dokter, verpleegster, besigheidsman, prokureur, akademikus en vakrnan ook te figureer in Afrikaanse kinder-en jeugliteratuur.

'n Groter sensitiwiteit is nodig vir die gevoelens van swart kinders en 'n groter besef van hoe literatuur hulle selfbeeld kan vernietig of opbou.

Sosio-politieke en -ekonomiese probleme van swartes behoort nie aanvaar te word as onvermydelik of as die skuld van die swarte alleen nie. 'n Mate van insig, afhangende van die ouderdomsgroep vir wie die literatuur bedoel is, behoort van die ware oorsake gegee te word. Verdraagsaamheid en eerbied vir sosiale en kulturele verskille behoort gekweek te word en vooroordele en foutiewe assumpsies teengewerk te word.

Afrikaanse kinder- en jeugliteratuur kan dit nie meer bekostig om 'n wêreld uit te beeld gesien net vanuit 'n blanke oogpunt nie. In hierdie verband is dit gepas om ten slotte te vra: Waar is die gekleurde Afrikaanssprekende kinder- en jeugboekskrywers van Suid-Afrika?

\section{BIBLIOGRAFIE}

BECKER, JÖRG. 1977 : Alltäglicher Rassismus: die afro-amerikanischen Rassenkonflikte im Kinder-und Jugendbuch der Bundesrepublik. Frankfurt: Campus Verlag

BENZING, BRIGITTA. 1978 : "Das Land war immer besser als die Leute. Afrika und Afrikander im Kinder-und Jugendbuch", pp. 58-89 in Jörg Becker und Rosmarie Rauter (Hrsg.), Die dritte Welt im Kinderbuch. Wiesbaden: Akademische Verlagsgesellschaft

BRODERICK, DOROTHY. 1973 : Image of the black in children's fiction. New York: R.R. Bowker

DIXON, BOB. 1977 : Catching them young 1: sex, race and class in children's fiction. London: Pluto Press

GROSSE-OETRINGHAUS, H-M \& G HERHOLZ. 1978 : "Das Afrikabild in bundesdeutschen Judgendbücher"

MILNER, DAVID. 1975 : Children and race. Harmondsworth, Middlesex: 


\section{Penguin Books}

PREISWERK, ROY, ed. 1980 : The slant of the pen: racism in children's books ed. by Roy Preiswerk. Geneva: World Council of Churches REDMOND, ROLINE. 1980 : Zwarte mensen in kinderboeken. Den Haag: Nederlands Bibliotheek en Lektuur Centrum (Buiten het boekje 19)

ROSEMBERG, FULVIA. 1980 : "Ethnisch-rassische Diskriminierung in der brasilianischen Kinder-und Jugendliteratur". Informationen des Arbeitskreises für Judgendliteratur. V. 1: 53-63

SADKER, MYRA POLLACK \& DAVID MILLER SADKER. 1977 : Now upon a time: a contemporary view of children's literature. New York: Harper \& Row

SMITH, B L, LASWELL, H D \& CASEY, R D. 1946 : Propaganda, communication and public opinion. Princetown University Press TÖ̈TEMEYER, ANDREE-JEANNE. 1984 : The racial element in Afrikaans children's and youth literature. D. Phil. University of Stellenbosch (Unpublished thesis)

\section{LYS VAN AANGEHAALDE KINDER- EN JEUGVERHALE}

ANS. 1948 : Booi en sy maats. Kaapstad: Nasionale Pers.

AREND, BEN. 1955 : Fanie, die jong speurder van Doornbos. Kaapstad: Nasionale Boekhandel Beperk.

BLOM, J J. 1942 : Die boggies van die Bosberg: grepe uit die lewe van 'n span plaasseuns. Kaapstad: Nasionale Pers.

BOEROP, L J. 1945 : Doea gaan tronk toe. Pretoria: Van Schaik.

BOERNEEF, pseud vir I W VAN DER MERWE. 1938 : Pensie. Kaapstad: Nasionale Pers.

BOERNEEF, pseud vir I W VAN DER MERWE. 1939 : Van my kinderdae. Kaapstad: Nasionale Pers.

BOERNEEF, pseud vir I W VAN DER MERWE. 1948 : Vlettervlie en Koesnaatije en ander verhale. 2de druk. Kaapstad: Nasionale Pers. BOSMAN, REN. 1945 : Saam met Lonkies. Pretoria: Van Schaik. BOUWER, ALBA. 1955 : Stories van Rivierplaas. Kaapstad: Nasionale Boekhandel.

BOUWER, ALBA. 1956 : Nuwe stories van Rivierplaas. Kaapstad: Nasionale Boekhandel.

BOUWER, ALBA. 1958 : Abdoltjie; ses verhaaltjies oor 'n Maleiertjie van die ou Kaap. Kaapstad: Nasionale Boekhandel.

BOUWER, ALBA. 1961 : Katrientjie van Keerweder. Kaapstad: Tafelberg.

BOUWER, ALBA. 1966 : Dirkie van Driekuil. Kaapstad: Tafelberg. 
BOUWER, ALBA. 1971 : 'n Hennetjie met kuikens. Kaapstad: Tafelberg. BOUWER, ALBA. 1979 : "Oupa Kyken" Pp. 11-22 in Storiehuis woordpaleis, 'n keur nuwe kinderverhale en -verse ... byeengebring deur die Instituut vir Navorsing in Kinder- en Jeuglektuur PU vir CHO. Kaapstad: Tafelberg.

BREWIS, LULU. 1935 : Niko die dromer: 'n kinderverhaal uit die dae van die Groot Trek. Kaapstad: Nasionale Pers.

CILLIÉ, HETTIE : Chrissie en Joey: twee niggies op 'n kosskool. Pretoria: Van Schaik.

D'ARBEZ pseud vir J F VAN OORDT : De Grensbewoners: een histories verhaal uit de dagen van de eerste en tweede opstand te Graaff-Reinet in de jaren 1795 en 1799. Pretoria: J H de Bussy.

DE VILLIERS, P. 1948 : "Uilkraal se spook". Pp. 32-41 in Ons MaatsJaarboek saamgestel deur Sarel Marais. Johannesburg: Afrikaanse Pers-Boekhandel.

DE WAAL, J H H. 1939 : Die Eksentrieke Essie (Versamelde Werke Deel II) In die spelonk. In sy wilskrag getoets (Versamelde Werke Deel VI). Oupa en sy kleindogters: 'n geskiedkundige roman (Versamelde werke Deel VI). Sy wilskrag getoes (Versamelde Werke Deel V) Woorde en dade. In Lucie. (Stukke uit "Stompies") (Versamelde Werke Deel VI) Kaapstad: Nasionale Pers.

DU PLESSIS, I D. 1939 : Uit die Slamse Buurt. Deel I en Deel II Kaapse sprokies, fabels en legendes. Kaapstad: Nasionale Pers.

DU PLESSIS, I D. 1943 : Die gevleuelde perd en ander Kaapse verhale. Pretoria: Van Schaik.

ERASMUS, P. 1942 : Twee Voortrekkertjies. Kaapstad: Nasionale Pers. FOURIE, J P. (1970) : Malupi. Pretoria: J P van der Walt.

FRANZ, G H. 1954 : Rabodutu die eensame. Kaapstad: Nasionale Boekhandel.

GROBBELAAR, P W. 1968 : Die mooiste Afrikaanse sprokies. Kaapstad: Human en Rousseau.

GROENEWEG, J J. 1925 : Waar die doringbome fluister: 'n boek vir jongmense. Pretoria en Kaapstad: $\mathrm{J} H$ de Bussy: $\mathrm{H} \mathrm{A} \mathrm{U} \mathrm{M}$

GROENEWEG, J J. 1943 : Drie straatsangers in die Kongo. Pretoria: $J \mathrm{~L}$ van Schaik.

HENDRIKS, HERMIE. 1949 : Berg van grafte. Johannesburg: Voortrekker Pers.

HICKEY, W A. 1981 : Manela die olifantbul. Pretoria: Juventus. HEESE, HESTER. 1966 : Loekie, die rondlopertjie. Kaapstad: Tafelberg. HEESE, HESTER. 1970 : Ek en jy, Grootbroer. Kaapstad: Tafelberg. HEESE, HESTER. 1978 : Wannelas. Kaapstad: Tafelberg. 
HEESE, HESTER. 1981 : Die geluid van wakker. Kaapstad: Tafelberg. HOBSON, SAM EN GEORGE CAREY. 1930 : Skankwan van die duine. Pretoria: Van Schaik (3de uitgawe 1977).

KOCK, H F. 1943 : Kaskenades en wederwaardighede: verhaaltiies vir die jongspan. Kaapstad: Nasionale Pers.

LAMPRECHT, I D. 1979 : Die speurders van Waterval. Pretoria: De Jager - $\mathrm{H} \mathrm{A} \mathrm{U} \mathrm{M.}$

LANGENHOVEN, C J. 1933 : "Die Krismiskinders". Pp. 273-373 in Versamelde Werke Deel V. Kaapstad: Nasionale Pers.

LINDE, FREDA. 1964 : Snoet-Alleen. Kaapstad: John Malherbe.

LINDE, FREDA. 1973 : Die singende gras. Kaapstad: Tafelberg.

LINDE, FREDA. 1980 : 'n Tuiste vir Bitis. Kaapstad: Tafelberg.

LOOTS, WILLEM F. 1961 : Boerseun bo! of Die handjie op die klip. 'n Roman. Roodepoort: Christelike Uitgewersmaatskappy.

MAARTENS, MARETHA. 1984 : 'n Pakkie mieliepitte. Kaapstad: Tafelberg.

MARAIS, ANNALOU. 1977 : Fransie, Sannie en die skaapdief. Piet Retief: Fonteine Publikasies.

MARAIS, EUGÉNE N. 1964 : Dwaalstories (Prosaverhale). Kaapstad: Human en Rousseau (3de druk; 1ste druk 1927).

MARTIN, EARL. 1978 : Moriti; 'n jeugverhaal. Pretoria: Daan Retief. M E R, pseud vir M E ROTHMANN. 1921 : Kinders van die Voortrek. Bloemfontein: De Nationale Pers Beperkt.

ME R, pseud vir M E ROTHMANN. 1934 : Karlien en Kandas. Kaapstad: Nasionale Pers (2de uitgawe 1969, Nasionale Boekhandel)

MILES, JOHN. 1980 : Stanley Bekker en die boikot. April-Mei 1980. (Die Ander Afrikaanse leesboekies Nr. 1). Johannesburg: Taurus.

MÖLLER-MALAN, D. 1961 : Tshikobani, seun van die Senzi. Pretoria: $J P$ van der Walt.

NEL, JEANNETTE. 1944 : Klein trekboertjies. Kaapstad: Nasionale Pers. NIENABER, G S. 1942 : Die heldin van Klipspruit. Kaapstad: Nasionale Pers.

NORTJÉ, COR. 1979 : Tekkies en die sluipmoord. Kaapstad: Tafelberg. NORTJÉ, P H. 1970 : In voetpad se kloof. Kaapstad: Tafelberg.

OLIVIER, PHIL. 1957 : Die bende en die grot van Mamoesa. Kaapstad: N G Kerk Uitgewers.

OLWAGEN, J D. (1930) : "Kinders van die Kaliharie" Pp. 1-17. "Ou Geelbooi" Pp. 18-24 in Vier Kinderstories. Kaapstad: Juta.

RAUTENBACH, E. 1944 : Kinders van die grens: 'n verhaal vir kinders. Kaapstad: J H de Bussy.

RETIEF, B R. 1964 : Drietal langs die Okavango. Pretoria: J L van Schaik. 
RUPERT, RONA. 1972 : Molisana, die seun wat die kleiosse maak. Kaapstad: Human \& Rousseau.

RUPERT, RONA. 1974 : Wat maak jy, Hektor? Kaapstad: Talelberg. RUPERT, RONA. 1976 : Luister, Lefa. Kaapstad: Human \& Rousseau. RUPERT, RONA. 1980 : Die aarbeimense. Kaapstad: Human \& Rousseau.

RUPERT, RONA. 1984 : Al Everest se voëls. Kaapstad: Human \& Rousseau.

SAUNDERS, ELIZABETH. 1939 : Na die storm. Kaapstad: Nasionale Pers.

SCHOEMAN, P J. 1945 : Op die klein spoortjies. Kaapstad: Nasionale Boekhandel.

SCHOEMAN, P J. 1948 : Fanie se veldskooldae. Johannesburg: Voortrekkerpers.

SCHOEMAN, P J. 1960 : Fanie se vuurdoop. Johannesburg: Voortrekkerpers.

SEYMORE, J D. 1931 : Outa Danster en Aia Martha. Kaapstad: Nasionale Pers.

SITA, pseud vir S S DE KOCK. 1937 : Janette: 'n dogter wat geen dame wou word nie. Johannesburg: Afrikaanse Pers Beperk (2de druk 1939; 2de uitgawe 1963; 3de uitgawe 1972, Perskor).

SITA, pseud vir S S DE KOCK. 1938 : Outa Fransie en ander verhale. Pretoria: Van Schaik.

SITA, pseud vir S S DE KOCK. 1956 : Mientjie en die Tokkelossie. Johannesburg: Voortrekkerpers.

SLEIGH, DAN. 1977 : Sersant Barodien, Kaapse Korps. Kaapstad: Tafelberg.

SMITH, JURGEN. 1951 : Amakeia (Twee Kinderkersverhale). Johannesburg: Afrikaanse Pers Beperk.

SPENCE, ELA. (1945) : "Die swart kaboutertjies" Pp. 108-111 in Ons Kinderjaarboek Nr. 4 saamgestel deur Sita. Johannesburg: Afrikaanse Pers-Boekhandel.

SPENCE, ELA. 1948 : "Die swart babetjie" Pp. 39-45 in Ons Kinderjaarboek Nr. 7 saamgestel deur Sita. Johannesburg: Alrikaanse PersBoekhandel.

STEENBERG, ELSABÉ. 1975 : Korrel en Kuif. Johannesburg: Perskor. STEENBERG, ELSABÉ. 1978 : Koert se tarentaal. Kaapstad: Tafelberg. TE GROEN. SANET. 1980 : Benman van die Bosveld. Pretoria: Daan Retief.

THEUNISSEN, M H. 1932 : Drosters: twee boeiende verhale vir kinders. Kaapstad: Nasionale Pers. 
VAN BLERK, H S. 1979 : Faanman slaags met terroriste (Blou Tartarereeks). Kaapstad: Tafelberg.

VAN DEN BERG, J. 1957 : Soois op die spoor. Kaapstad: Nasionale Boekhandel.

VAN DEN BERG, J. 1963 : Soois op die plaas. Kaapstad: Tafelberg (3de druk 1970).

VAN DER MERWE, H W. 1958 : Aanstap! Voorwaarts! Johannesburg: Afrikaanse Pers Boekhandel.

VAN DER POST, J J. 1963 : Kind van die duine. Kaapstad: Tafelberg. VAN DER POST, J J. 1964 : Vonk, vondeling van die duine. Kaapstad: Tafelberg.

VAN DER SPUY, CECIL. 1943 : Stinkie of Die Immer-Nimmer-Land. Kaapstad: Nasionale Boekhandel Beperk.

VAN HEERDEN, ETIENNE. 1978 : Matoli. Johannesburg: Perskor. VAN SCHALKWYK, N. 1978 : Ngonyoma keer terug; die avonture van Kristof en die slaweseun, Kobo. Pretoria: Daan Retief.

VAN STRATEN, C. 1979 : Fesito gaan mark toe. Kaapstad: Human \& Rousseau.

VAN STRATEN, C. 1979 : Kaninu se geheim. Kaapstad: Human \& Rousseau.

VAUGHAN, K L \& A O. 1910 : Ou Hendrik z'n stories. Londen: Longmans, Green \& Co.

VENTER, BEN. 1971 : Salmaklak: 'n legende van Vaalrivier. Johannesburg: Voortrekkerpers.

VENTER, F A. 1965 : Wit Oemfaan: Gegrond op die verhaal van die Voortrekkerseun Ferdinand Paulus van Gass soos aangeteken deur Gustav S Preller. Kaapstad: Tafelberg.

VAN HÖRSTEN, H en FRITZ. 1946 : Lank lewe die Bushies. Johannesburg: Afrikaanse Pers Boekhandel ('n Nuwe gesuiwerde uitgawe het in 1962 verskyn sonder vermelding van die feit dat veranderings aangebring is).

VAN HÖRSTEN, H en FAITZ. 1948 : "Vakansie op die plaas" Pp. 84-94 in Ons Maats-Jaarboek saamgestel deur Sarel Marais. Johannesburg: Afrikaanse Pers-Boekhandel.

VON WIELLIGH, G R. 1919 : Boesmanstories (Deel I) Mitologie en legendes. Kaapstad: Nasionale Pers.

VON WIELLIGH, G R. 1922 : Dierstories en ander verhale (Deel 2). Kaapstad: Nasionale Pers.

VON WIELLIGH, G R. 1924 : Gwennie Barneveld. Pretoria: Van Schaik (2de druk). 